\title{
MOLECULAR DOCKING OF AMITRIPTYLINE TO CERULOPLASMIN, RETINOL-BINDING PROTEIN, AND SERUM ALBUMIN
}

\author{
RAMCHANDER MERUGU ${ }^{1}$, KALPANA V SINGH ${ }^{2 *}$ \\ ${ }^{1}$ Department of Biochemistry, University College of Science, Mahatma Gandhi University, Nalgonda, Telangana, India. ${ }^{2}$ Department of \\ Chemistry and Pharmaceutical Chemistry, Government Madhav Science Postgraduate College, Ujjain, Madhya Pradesh, India. \\ Email: singhkalpana297@gmail.com
}

Received: 22 August 2017, Revised and Accepted: 07 November 2017

ABSTRACT

Objective: A drug's efficiency depends on the binding capacity of the drug with the particular plasma protein. The less bound drug can be easily diffused through cell membranes. The present study deals with in silico studies of amitriptyline binding to three plasma proteins human ceruloplasmin (HCP), cellular retinol-binding protein (CRBP), and human serum albumin (HSA) and tries to establish the binding capacity behavior with the frontier molecular orbital approach.

Methods: Amitriptyline is selected as legend and docked with three plasma proteins HCP, HCP PDB ID 1KCW, CRBP PDB ID 5LJC, and HSA. Docking calculations were carried out using docking server. frontier molecular orbital calculations are performed through web-based computational chemistry interface WEBMO version 17.0.012e using server Buchhner.chem.hope.edu. on computational engine MOPAC.

Results: HCP and HSA predominantly show polar and hydrophobic interactions, whereas CRBP forms hydrogen bond apart from polar and hydrophobic interactions. Favorable values of inhibition constant, Ki, is obtained which is equal to $1.13 \mu \mathrm{M}$ for CRBP, $6.00 \mu \mathrm{M}$ for $\mathrm{HCP}$, and $2.00 \mu \mathrm{M}$ for has.

Conclusion: A studies prove that amitriptyline can bind to all three plasma proteins, namely, HCP, CRBP, and HSA. Amitriptyline binds to an HSA and HCP through polar and hydrophobic interactions while weak electrostatic interactions felicitate diffusion of amitriptyline through the plasma membrane. Comparatively, strong hydrogen bond in CRBP may make the bound drug to be released at a slow rate. Strong binding of amitriptyline to $\mathrm{CRBP}$ is also evident from the least value of inhibition constant, $\mathrm{Ki}$, which is equal to $1.13 \mu \mathrm{M}$ for $\mathrm{CRBP}, 6.00 \mu \mathrm{M}$ for $\mathrm{HCP}$, and $2.00 \mu \mathrm{M}$ for has.

Keywords: Human ceruloplasmin, Retinol-binding protein, Human serum albumin, Amitriptyline.

(C) 2018 The Authors. Published by Innovare Academic Sciences Pvt Ltd. This is an open access article under the CC BY license (http://creativecommons. org/licenses/by/4. 0/) DOI: http://dx.doi.org/10.22159/ajpcr.2018.v11i2.22721

\section{INTRODUCTION}

Human ceruloplasmin (HCP), $(1 \mathrm{KCW})$ is a member of the multicopper oxidase family of enzymes [1]. It was first isolated in 1944 [2] and has a molecular weight of some $132 \mathrm{kDa}$, being comprised of a single polypeptide chain of 1046 amino-acid residues with a carbohydrate content of between $7 \%$ and $8 \%$ [3]. The first X-ray structural study of HCP was reported in 1996 [4]. Copper is required for a wide variety of enzymatic reactions taking place in living cells [5-9]. CP physically interacts with transferrin, and it acts as a ferroxidase and is thought to mediate efflux of iron from cells, [10-12]. Cp does play a role in the transfer of Fe (II) to blood plasma transferring from some cells-like hepatocytes [13-15]. The arrangements of the trinuclear center and the mononuclear copper ion are similar to that of laccase and ascorbate oxidase [16-19]. Cellular retinol-binding protein (CRBP) appears to have several roles, including (1) delivering retinol to specific binding sites within the nucleus and (2) participating in the transepithelial movement of retinol across certain blood-organ barriers. Vitamin A is transported to the tissues in the form of retinol bound to RBP in a 1:1 complex and is largely regulated by the turnover rates of RBP [20]. Plasma RBP has 93\% sensitivity for predicting marginal Vitamin A status [21]. Human serum albumin (HSA), is the most abundant protein in plasma, which is a main modulator of fluid distribution between body compartments [22-23]. HSA acts as a main carrier for fatty acids, affecting pharmacokinetics of many drugs, provides the metabolic modification of some ligands, renders potential toxins harmless, accounts for most of the antioxidant capacity of human plasma, and displays (pseudo-) enzymatic properties [24-29]. HSA is a valuable biomarker of many diseases [30-32] with potential applications as implantable biomaterials, surgical adhesives, sealants, and fusion proteins [33-35]. Albumin functions primarily as a carrier protein for different biomolecules. Mutations in this gene on chromosome 4 result in various anomalous proteins. Plasma proteins serve many functions including transport of drugs, lipids, hormones, vitamins, and minerals in the circulatory system. Serum Albumin accounts for $55 \%$ of plasma proteinsand most drugs screen for serum albumin only. Hence, in the present study, binding of the drug amitriptyline to other plasma proteins was investigated along with albumen. Docking technique used in the in silico studies predicts the binding of one molecule to the other through preferential orientations of the molecules. Different parameters such as free energy of binding, polar and hydrophobic interactions, and formation of hydrogen bond are identified during docking, and in silico studies are used extensively for studying the docking behavior $[36,37]$

\section{METHODS}

Amitriptyline is selected as legend and docked with three plasma proteins HCP, HCP PDB ID 1KCW, CRBP PDB ID 5LJC, and HSA. Docking calculations were carried out using docking Server [38]. Gasteiger partial charges are added to the ligand atoms by the server during docking, non-polar hydrogen atoms are merged, and rotatable bonds are defined. As per server notification, AutoDock tools [39] are used for adding essential hydrogen atoms, Kollman united atom type charges, and solvation parameters. Autogrid program [39] generated affinity grid maps of $\times \AA$ and $0.375 \AA$. AutoDock parameter set- and distance-dependent dielectric functions are used in the calculation of van der Waals and electrostatic terms, respectively. Lamarckian genetic algorithm and the Solis and Wets local search methods [40] are used for performing docking simulations. Initial position, 
orientation, and torsions of the ligand molecule are set randomly. All rotatable torsions are released during docking. 10 different runs, terminating after a maximum of 250,000 energy evaluations, are used for each docking experiment. Population size is 150 , a translational step of $0.2 \AA$, and quaternion and torsion step of 5 are applied. Frontier molecular orbital calculations are performed through webbased computational chemistry interface WEBMO version 17.0.012e using server Buchhner.chem.hope.edu. on computational engine MOPAC.

\section{RESULTS AND DISCUSSION}

The interaction between the ligand and the target protein $1 \mathrm{KCW}$ is shown in Figs. $1 \mathrm{a}, \mathrm{b}$ and 2 . Tables 1 and 2 show the interaction energies involved in the binding of the ligands to the $1 \mathrm{KCW}$. According to docking server, inhibition constant is $6.00 \mathrm{um}$. Ki is reflective of the binding affinity. If $\mathrm{Ki}$ is much larger than the maximal plasma drug concentrations, a patient is exposed to from typical dosing, then that drug is not likely to inhibit the activity of that enzyme. Smaller the Ki, the smaller amount of medication is needed to inhibit the activity of that enzyme. The value obtained here is $6.00 \mathrm{uM}$, which lies well within the limits. The estimated free energy of binding is about $-7.12 \mathrm{kcal} /$ Mol (Table 1). According to the docking server (Table 2), polar bond is formed between ASN119 of target and N1 and H1 of ligand, which is again indicative of the docking between target and ligand. Excellent electrostatic interactions of polar, hydrophobic, pi-pi, and van der Waals interactions are observed (Table 2). Inhibitions constant (Ki) $6.00 \mathrm{uM}$ is favorable for the interaction. Docking results give binding site analysis for 6 amino acids, with the ligand which shows precise conformity.
The ligand amitriptyline interacted well with the protein $1 \mathrm{KCW}$ in the docking grid.

Table 3 summarizes the molecular docking energy level table for drug amitriptyline to 5LJC (RBP). According to docking server, inhibition constant is $1.13 \mathrm{uM}$. The value obtained here is 1.13 $\mathrm{uM}$, which lies well within the limits. The estimated free energy of binding is about $-8.11 \mathrm{kcal} / \mathrm{Mol}$ (Table 3 ). The interaction between the ligand and the target protein $5 \mathrm{LJC}$ is presented in Figs. $3 \mathrm{a}, \mathrm{b}$ and 4. Polar interactions between $\mathrm{N}$ of amitriptyline and MET 119 residue of 5LJC hydrophobic and other interactions are also seen (Table 4)

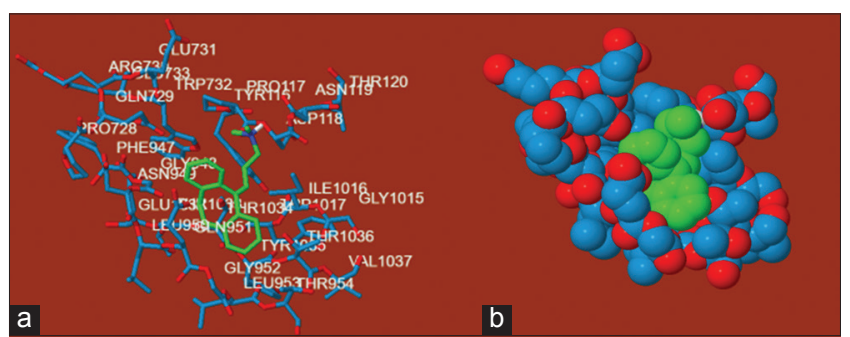

Fig. 1: (a and b) Docking of amitriptyline to $1 \mathrm{KCW}$ polar interactions between $\mathrm{N}$ of amitriptyline and ASN 119 residue of IKCW | hydrophobic and other interactions are also seen. Docking results obtained from docking server. Ligand represented by Greenside chains by blue and red color

Table 1: Molecular Docking energy level table for drug amitriptyline to $1 \mathrm{KCW}$

\begin{tabular}{llllll}
\hline $\begin{array}{l}\text { EST. Free energy } \\
\text { of binding }\end{array}$ & $\begin{array}{l}\text { EST. Inhibition } \\
\text { constant, Ki }\end{array}$ & $\begin{array}{l}\text { vdW+Hbond+dissolve } \\
\text { energy }\end{array}$ & $\begin{array}{l}\text { Electrostatic } \\
\text { energy }\end{array}$ & $\begin{array}{l}\text { Total intermolecular } \\
\text { energy }\end{array}$ & Frequency \\
\hline$-7.12 \mathrm{kcal} / \mathrm{Mol}$ & $6.00 \mathrm{uM}$ & $-6.54 \mathrm{kcal} / \mathrm{Mol}$ & $-1.21 \mathrm{kcal} / \mathrm{Mol}$ & $-7.75 \mathrm{kcal} / \mathrm{Mol}$ & $50 \%$ \\
\hline
\end{tabular}

Table 2: Bonds formed between amitriptyline to $1 \mathrm{KCW}$

\begin{tabular}{|c|c|c|}
\hline Polar & Hydrophobic & Others \\
\hline $\begin{array}{l}\text { N1 O [3.39] - ASN119 (ND2, OD1) } \\
\text { H1 O [2.66] - ASN119 (ND2, OD1) }\end{array}$ & $\begin{array}{l}\text { C20 O [3.42] - TRP732 (CD1) } \\
\text { C8 } 0 \text { [3.78] - ILE1016 (CD1) } \\
\text { C9 } 0 \text { [3.67] - ILE1016 (CD1) } \\
\text { C9 } 0 \text { [3.28] - ILE1016 (CD1) }\end{array}$ & $\begin{array}{l}\text { H1 O [2.60] - ASN119 (CB, CG) } \\
\text { N1 O [3.55] - ASN119 (CG) } \\
\text { C14 O [3.77] - ASN119 (ND2) } \\
\text { C19 O [3.41] - ASN119 (ND2) } \\
\text { C16 O [3.06] - GLN729 (OE1) } \\
\text { C18 O [3.83] - GLN729 (OE1) } \\
\text { C11 O [2.95] - GLN951 (OE1) } \\
\text { C16 O [3.14] - GLN951 (OE1) } \\
\text { C1 O [3.66] - GLN951 (OE1) } \\
\text { C2 O [3.89] - GLN951 (OE1) } \\
\text { C5 O [3.20] - GLN951 (OE1) } \\
\text { C7 O [3.62] - GLN951 (OE1) } \\
\text { C13 O [3.75] - GLN951 (OE1) } \\
\text { C18 O [3.53] - GLN951 (OE1) } \\
\text { C2 O [3.73] - THR1033 (OG1) } \\
\text { C2 O [3.15] - THR1034 (OG1) } \\
\text { C3 O [3.81] - THR1034 (OG1) } \\
\text { C8 O [3.38] - THR1034 (OG1) } \\
\text { C9 O [3.62] - THR1034 (OG1) } \\
\text { C17 O [2.83] - THR1034 (CBOG1) } \\
\text { C12 O [3.00] - THR1036 (OG1) } \\
\text { C15 O [3.69] - THR1036 (OG1) }\end{array}$ \\
\hline
\end{tabular}

Table 3: Molecular docking energy level table for drug amitriptyline to 5ljc (RBP)

\begin{tabular}{llllll}
\hline $\begin{array}{l}\text { EST. Free energy } \\
\text { of binding }\end{array}$ & $\begin{array}{l}\text { EST. Inhibition } \\
\text { constant, Ki }\end{array}$ & $\begin{array}{l}\text { vdW+Hbond+dissolve } \\
\text { energy }\end{array}$ & $\begin{array}{l}\text { Electrostatic } \\
\text { energy }\end{array}$ & $\begin{array}{l}\text { Total intermolecular } \\
\text { Energy }\end{array}$ & Frequency \\
\hline$-8.11 \mathrm{kcal} / \mathrm{Mol}$ & $1.13 \mathrm{uM}$ & $-8.89 \mathrm{kcal} / \mathrm{Mol}$ & $+0.03 \mathrm{kcal} / \mathrm{Mol}$ & $-8.86 \mathrm{kcal} / \mathrm{Mol}$ & $100 \%$ \\
\hline
\end{tabular}

RBP: Retinol-binding protein 
Table 5 shows the molecular docking energy level table for drug amitriptyline to serum albumin (1A06). According to docking server, inhibition constant is $2.0 \mathrm{uM}$. Ki is helpful in predicting that a particular ligand is going to inhibit a particular protein and results in a clinically relevant drug interaction with a substrate for the enzyme. $\mathrm{Ki}$ is reflective of the binding affinity. The value obtained here is
2.0 uM, which lies well within the limits. The estimated free energy of binding is about $-7.78 \mathrm{kcal} / \mathrm{Mol}$ (Table 5). The interaction between the ligand and the target protein 5LJC is presented in Figs. 5a, b and 6. Polar interactions between $\mathrm{N}$ of amitriptyline and GLU425 and GLN459 residue of serum albumin (Table 6). Hydrophobic and other interactions are also seen.

\begin{tabular}{lll}
\hline Polar & Hydrophobic & Other \\
\hline ASN119 (-0.5307) & TRP732 (-0.7408) & GLN951 (-0.6927) \\
& ILE101 $(-0.5498)$ & THR103 (-0.3705) \\
\hline
\end{tabular}

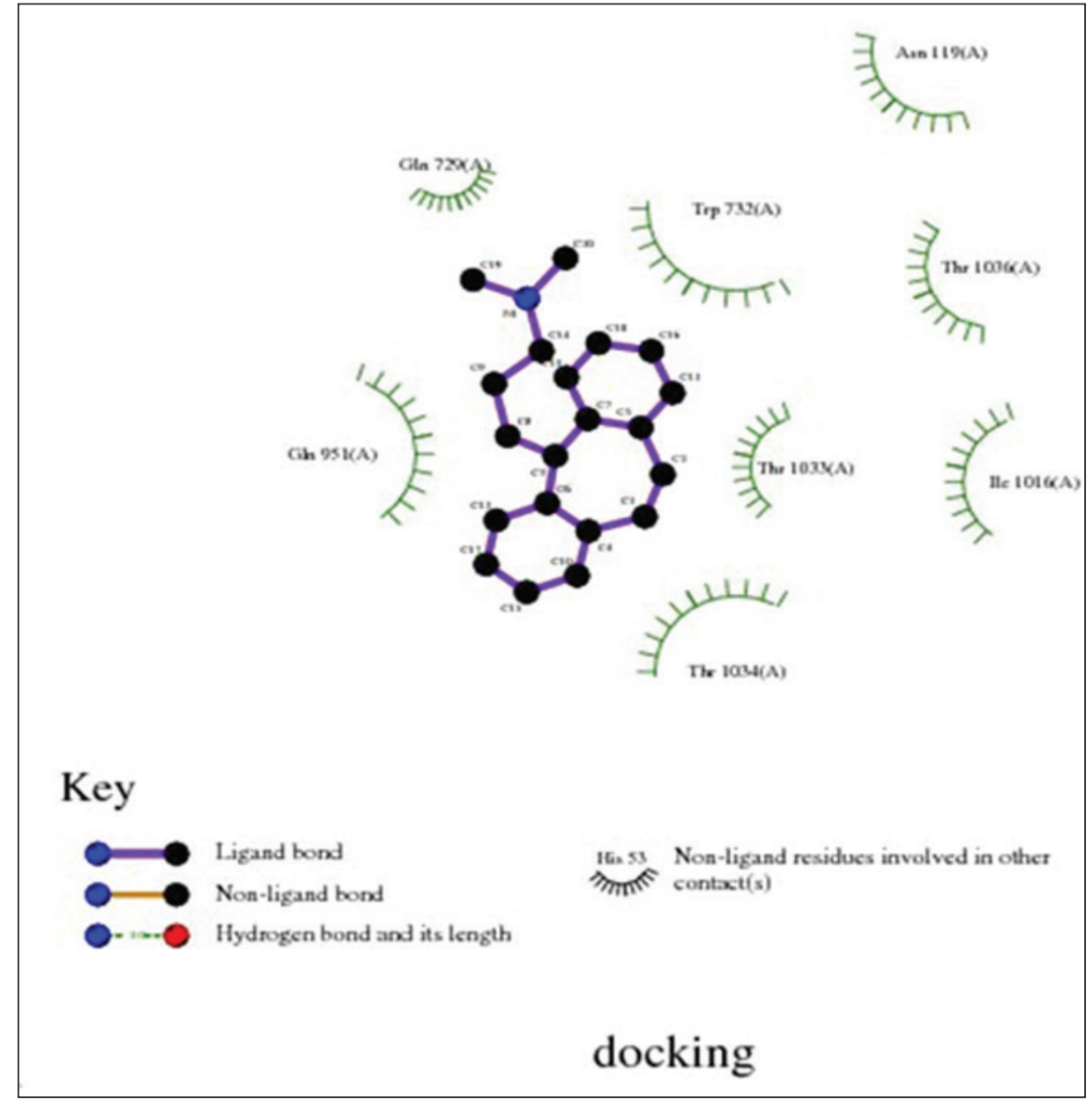

Fig. 2: Interaction among ligand and protein. Decomposed energies in Kcal/mole

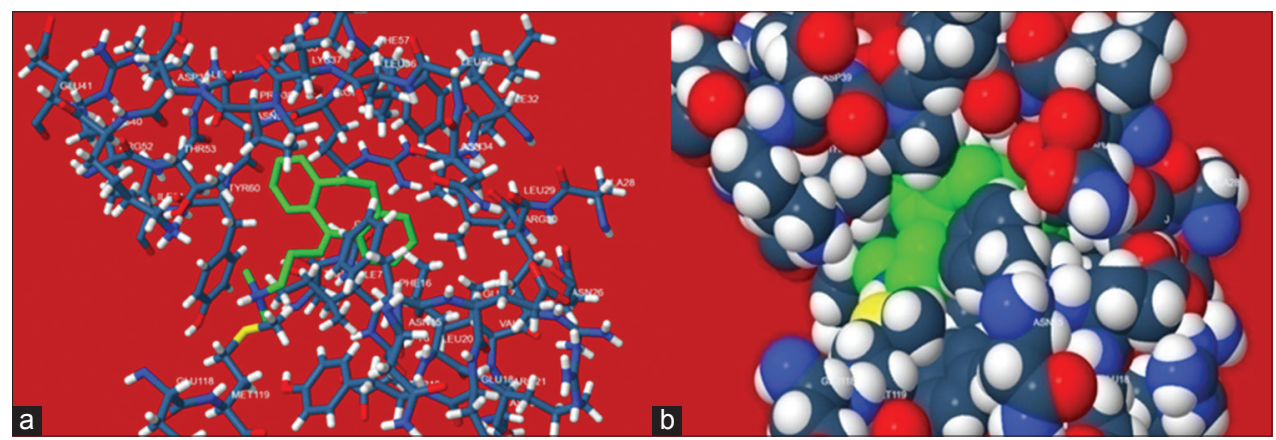

Fig. 3: (a and b) Docking of amitriptyline to 5L JC polar interactions between $\mathrm{N}$ of amitriptyline and MET 119 residue of $5 \mathrm{LJC}$ |hydrophobic and other interactions is also seen. Docking results obtained from docking server. Ligand represented by greenside chains by blue and red color 
Table 4: Bonds formed between amitriptyline and 5L JC

\begin{tabular}{|c|c|c|c|}
\hline Hydrogen bonds & Hydrophobic & pi-pi & OthSSers \\
\hline N1 0 [3.37] - MET119 (SD) & 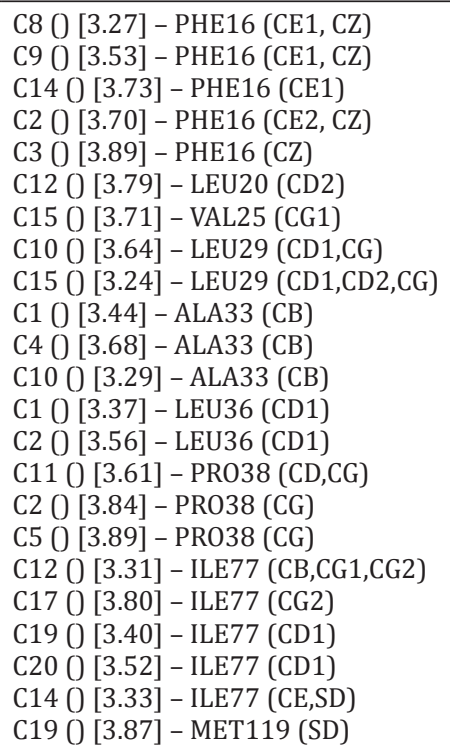 & $\begin{array}{l}\text { C13 () [3.76] - TYR60 (CB) } \\
\text { C18 () [3.50] - TYR60 (CB) }\end{array}$ & $\begin{array}{l}\text { C19 () [3.62] - TYR19 (OH) } \\
\text { C18 () [3.40] - THR53 (CB,CG2) } \\
\text { C16 () [3.44] - THR53 (CB,CG2) } \\
\text { C11 O [3.48] - SER55 (CB,OG) } \\
\text { C16 O [3.87] - SER55 (OG) } \\
\text { H1 () [2.67] - MET119 (CE,SD) }\end{array}$ \\
\hline
\end{tabular}

Table 5: Molecular docking energy level table for drug amitriptyline to serum albumin

\begin{tabular}{lllllll}
\hline $\begin{array}{l}\text { EST. Free energy } \\
\text { of binding }\end{array}$ & $\begin{array}{l}\text { EST. Inhibition } \\
\text { constant, Ki }\end{array}$ & $\begin{array}{l}\text { vdW+Hbond+dissolve } \\
\text { energy }\end{array}$ & $\begin{array}{l}\text { Electrostatic } \\
\text { energy }\end{array}$ & $\begin{array}{l}\text { Total intermolecular. } \\
\text { energy }\end{array}$ & Frequency & Interacting Surface \\
\hline$-7.78 \mathrm{kcal} / \mathrm{Mol}$ & $2.00 \mathrm{uM}$ & $-7.38 \mathrm{kcal} / \mathrm{Mol}$ & $-0.87 \mathrm{kcal} / \mathrm{Mol}$ & $-8.25 \mathrm{kcal} / \mathrm{Mol}$ & $50 \%$ & 677.752 \\
\hline
\end{tabular}

Table 6: Bonds formed between amitriptyline and serum albumin

\begin{tabular}{llll}
\hline Polar & Hydrophobic & pi-pi & Others \\
\hline N1 (1) [3.82] - GLU425 (OE2) & C10 (11) [3.37] - PRO147 (CD,CG) & C11 (12) [3.54] - HIS146 (CE1) & C7 (8) [3.85] - HIS146 (ND1) \\
N1 (1) [3.78] - GLN459 (OE1) & C15 (16) [3.86] - PRO147 (CD) & C13 (14) [3.79] - HIS146 (CE1) & C13 (14) [3.80] - HIS146 (ND1) \\
& & C16 (17) [3.28] - HIS146 (CE1) & C18 (19) [3.89] - HIS146 (ND1) \\
& & C18 (19) [3.40] - HIS146 (CE1) & C18 (19) [3.83] - LYS190 (CB,CG) \\
& C15 (16) [3.23] - TYR148 & C16 (17) [3.85] - LYS190 (CG) \\
& (CB,CD1,CG) & C17 (18) [3.18] - TYR148 (CB) & C13 (14) [3.51] - SER193 (CB,OG) \\
& & C3 (4) [3.42] - SER193 (OG) \\
& & C4 (4) [3.71] - SER193 (OG) \\
& & C6 (7) [3.03] - SER193 (OG) \\
& & C7 (4) [3.60] - SER193 (OG) \\
& & C12 (13) [2.83] - SER193 (OG) \\
& & C17 (18) [3.39] - SER193 (OG) \\
& & C12 (13) [3.28] - ARG197 (CB,CG) \\
& & C17 (18) [3.56] - ARG197 (CB,CD) \\
& & C19 (20) [3.20] - GLU425 (CD,CG,OE2) \\
& & C20 (21) [3.51] - GLU425 (OE2) \\
& & C14 (15) [3.22] - GLU459 \\
& & (CB,CD,CG,NE2,OE1) \\
& & C9 (10) [3.32] - GLN459 (CD,CG,NE2) \\
& & N1 (1) [3.68] - GLN459 (CD) \\
& & C20 (21) [3.11] - GLN459 \\
& & (CD,NE2,0E1) \\
& & C19 (20) [3.53] - GLN459 (OE1) \\
\hline
\end{tabular}

Table 7: Mopac semiempirical calculations

\begin{tabular}{ll}
\hline Route & Value \\
\hline Symmetry & $\mathrm{C}_{\mathrm{s}}$ \\
PM3 heat of formation & $1185.16374 \mathrm{Kal} / \mathrm{Mol}$ \\
Dipole moment & 0.918 Debye \\
Server & Buchhner.chem.hope.edu \\
CPU time & $0.47 \mathrm{~s}$ \\
\hline
\end{tabular}

The structure of amitriptyline of DFT studies is shown in Fig. 7. Squares of the wave function of electrons in the occupied molecular orbitals give the electron density Electron density isosphere (Fig. 8) predicts the size and shape of the molecule. Energy possessed by a unit charge at each point in space due to the surrounding electrons and nuclei is manifested in the form of electrostatic potential. Electrostatic potential is computed by integrating the electron density divided by a distance at each point in space. Electrostatic potential by convention is shown 


\begin{tabular}{lll}
\hline Hydrogen bonds & Hydrophobic & Others \\
\hline MET119 (0.0765) & ILE77 & THR53 0.7008 \\
& 1.3444 & \\
PHE16 & TYR19 0.4791 \\
& 1.1079 & \\
& LEU20 0.8783 & SER55 0.3603 \\
& TYR60 0.8752 & \\
& PRO38 0.7851 & \\
VAL25 0.4449 & \\
& LEU36 0.4084 & \\
& LEU29 0.4051 & \\
& ALA33 0.3952 & \\
\hline
\end{tabular}

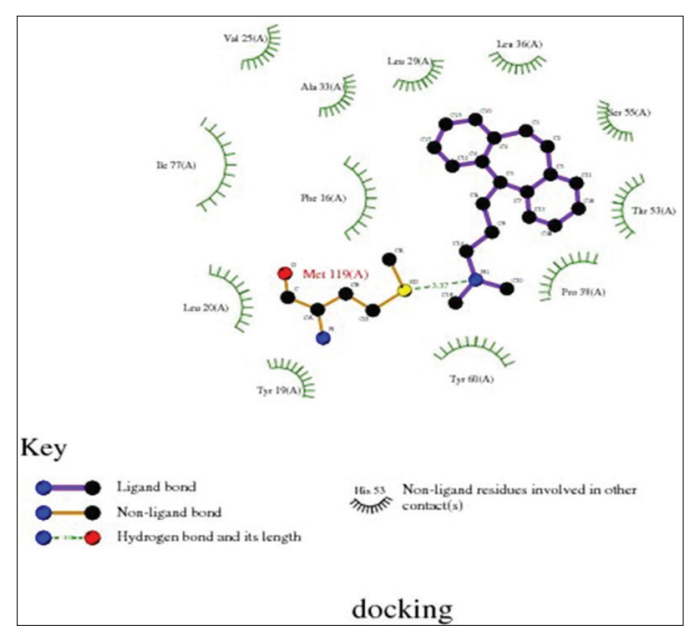

Fig. 4: Interaction among ligand and protein. Decomposed energies in $\mathrm{Kcal} / \mathrm{mole}$

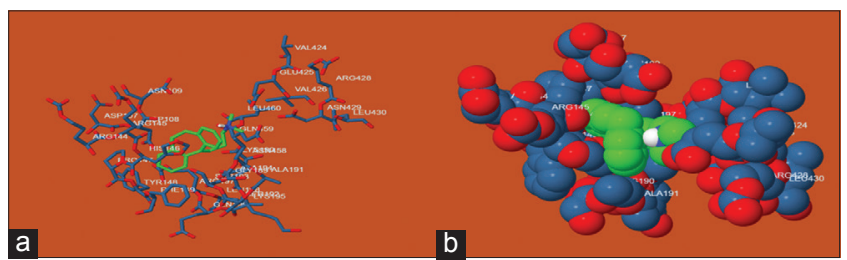

Fig. 5: ( $a$ and $b$ ) Docking of amitriptyline to serum albumin polar interactions between $\mathrm{N}$ of amitriptyline and GLU425, GLN459 residue of serum albumin|hydrophobic and other interactions is also seen. Docking results obtained from docking server. Ligand represented by greenside chains by blue and red color

on the electron density isosurface through different colors. By default, WebMO represents smaller values of red and larger values in blue. Thus, red represents negative regions, and blue represents positive regions on an electrostatic potential surface. The electrostatic potential surface on amitriptylineis red (negative) around methyl groups attached to nitrogen and blue (positive) around the 7 membered and six-membered rings. The magnitude of the molecular orbitals which are available for an attack by an electrophile or nucleophile or even by a radical is used for the computation of frontier density surfaces. Bull's eye pattern is used. Blue represents the largest possibility of attack. The electrophilic (HOMO) frontier density (Fig. 9a and b) is maximum around carbon at six-membered ring positioned toward nitrogen, indicating that protonation will occur at this position in molecular plane, whereas nucleophilic (LUMO) frontier density (Figs. 10, 11a and b) is maximum around nitrogen and methyl group joining the central sevenmembered ring, meaning that the nucleoplhilic attack will occur at this position. During the process of hydrogen bond formation as per the results obtained, $\mathrm{N}$ will play a strategic role amitriptyline binds to all the three plasma proteins discussed here in studies. As per the understanding, the active part of the drug is constituted mainly by the

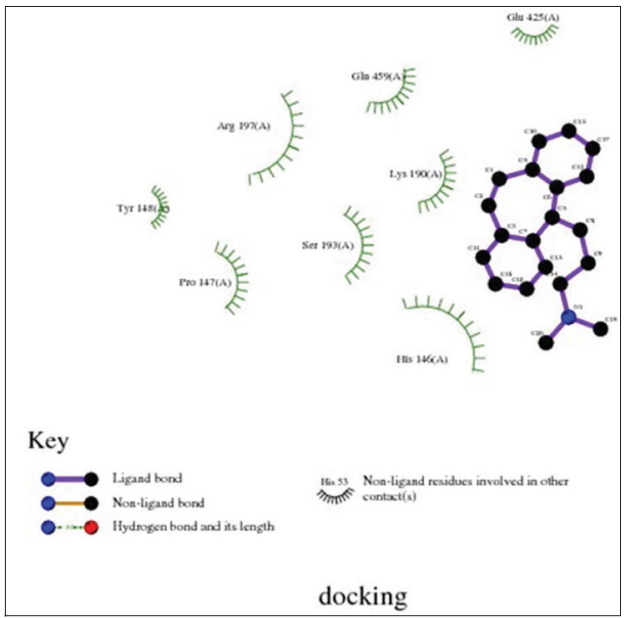

Fig. 6: Interaction among ligand and protein. Decomposed energies in $\mathrm{Kcal} / \mathrm{mole}$

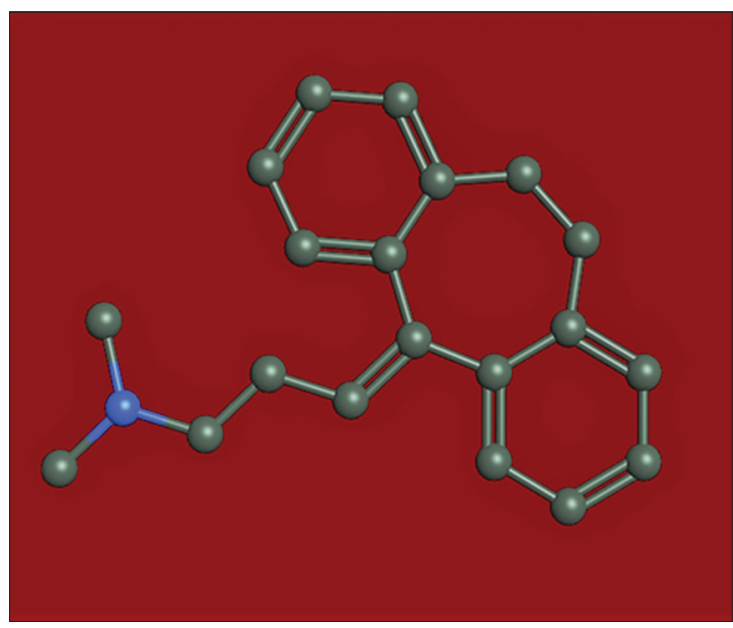

Fig. 7: Structure of amitriptyline

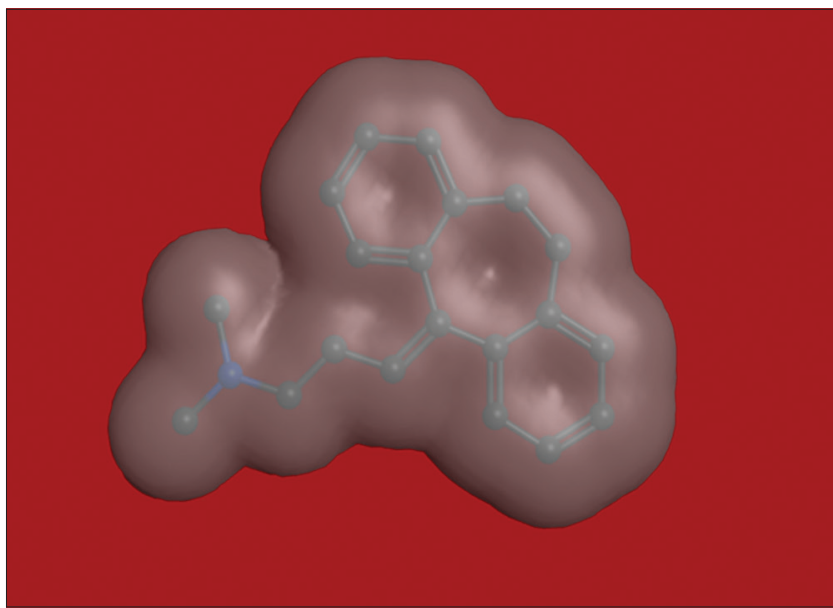

Fig. 8: Electron density in amitriptyline

unbound part of the drug. Bound drug is slowly released at the site as per the concentration changes. Studies here show that amitriptyline is a dipole with a dipole moment of 0.918 Debye (Fig. 12 and Table 7). The dipole is created along $\mathrm{N}$ chain joined to the seven-membered ring making $\mathrm{N}$ as a comparative negative pole with maximum electron density. Nucleophile attack takes place at this position leading to polar 


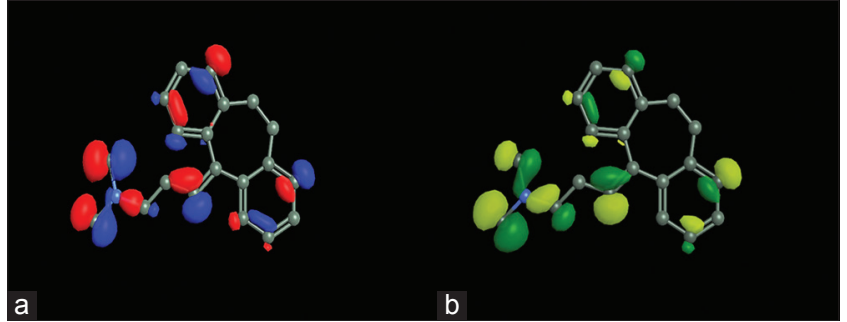

Fig. 9: (a) HOMO, HOMO ENERGY -298.143 ev, HOMO color red and blue, smaller values of red and larger values in blue, (b) LUMO of amitriptyline, LUMO ENERGY -293.913 ev, LUMO color yellow and green

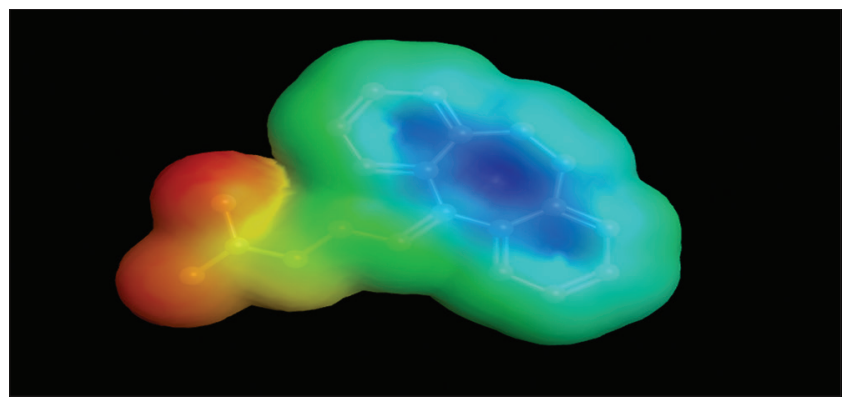

Fig. 10: Electrostatic potential isosurface in amitriptyline

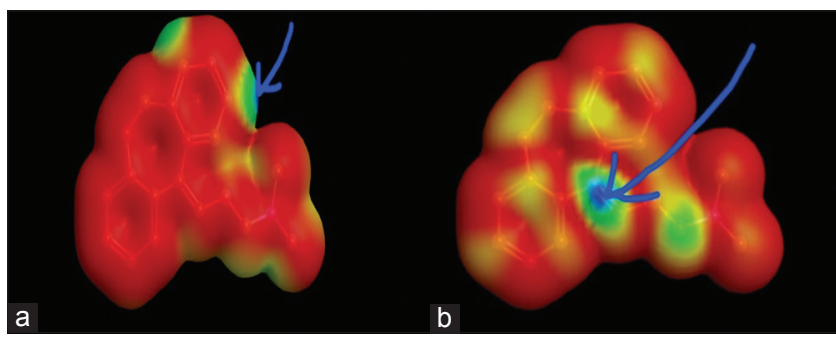

Fig. 11: (a) HOMO frontier density, (b) LUMO frontier density

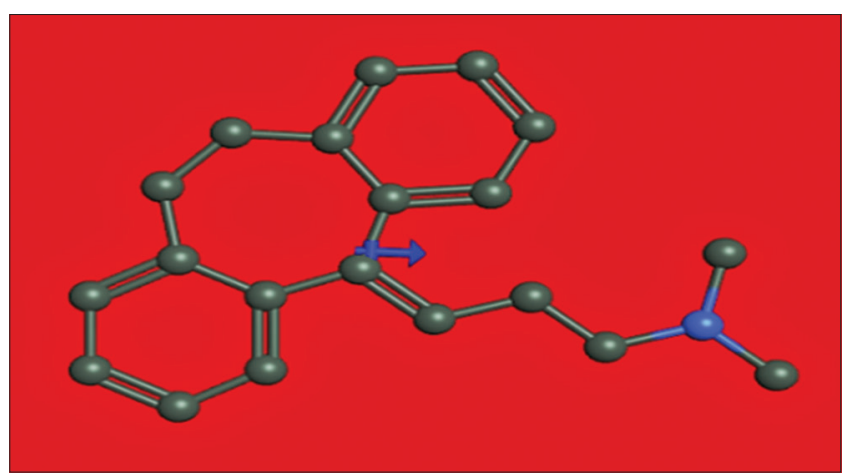

Fig. 12: Dipole moment in amitriptyline

interactions apart from hydrogen bonding. Electron cloud shifting toward nearby carbon atoms of amitriptyline leads to hydrophobic interactions. Very low HOMO LUMO energy gap in amitriptyline makes electron transfer easy from HOMO to LUMO creating condition for polar interactions, hydrophobic, van der Waals interactions, and electropillic and nucleophilic attack. Hydrogen bond formation is seen in case of interactions of amitriptyline with 5ljc. Hydrogen bond plays an important role in binding to the protein macromolecules. Hydrogen bond has the covalent type of characteristics, and narrow HOMO LUMO gap reestablishes the formation of hydrogen bond of appreciable bond length. No hydrogen bond is observed in case of amitriptyline interactions with $1 \mathrm{KCW}$ and amitriptyline interactions with $1 \mathrm{A06}$. Free energy of binding is negative in all the three cases, and value of inhibition constant is also very low. Polar and hydrophobic interactions are observed in all the three dockings with $1 \mathrm{KCW}, 5 \mathrm{Ljc}$, and $1 \mathrm{AO} 6$. HCP and HSA predominantly show polar and hydrophobic interactions, whereas CRBP forms hydrogen bond apart from polar and hydrophobic interactions. Polar and hydrophobic interactions in HAS and HCP make Amitriptyline bound to them, while weak electrostatic interactions felicitate diffusion of HAS and HCP through the plasma membrane. Comparatively, strong hydrogen bond in CRBP may make the bound drug to be released at slow rate. Strong binding of amitriptyline to CRBP is also evident from the least value of inhibition constant, $\mathrm{Ki}$, which is equal to $1.13 \mu \mathrm{M}$ for CRBP, $6.00 \mu \mathrm{M}$ for HCP, and $2.00 \mu \mathrm{M}$ for HAS.

\section{CONCLUSION}

Molecular docking of amitriptyline with ligands using docking server predicted in silico result with an inhibition constant, $\mathrm{Ki}$, which is equal to $1.13 \mu \mathrm{M}$ for CRBP, $6.00 \mu \mathrm{M}$ for HCP, and $2.00 \mu \mathrm{M}$ for HAS which agreed well with the physiological range for protein-ligand interaction. Polar and hydrophobic interactions in HAS and HCP make amitriptyline bound to them, while weak electrostatic interactions felicitate diffusion of HAS and HCP through the plasma membrane. Comparatively, strong hydrogen bond in CRBP may make the bound drug to be released at a slow rate.

\section{AUTHORS CONTRIBUTION}

Introduction and docking part by Dr. Ramchander Merugu. Discussion, Conlusion and DFT Calculations by Dr. Kalpana Virendra Singh.

\section{CONFLICTS OF INTEREST}

The authors whose names are listed immediately below certify that they have NO affiliations with or involvement in any organization or entity with any financial interest (such as honoraria; educational grants; participation in speakers' bureaus; membership, employment, consultancies, stock ownership, or other equity interest; and expert testimony or patent-licensing arrangements), or non-financial interest (such as personal or professional relationships, affi liations, knowledge or beliefs) in the subject matter or materials discussed in this manuscript.

\section{REFERENCES}

1. Bento I, Peixoto C, Zaitsev VN, Lindley PF. Ceruloplasmin revisited: Structural and functional roles of various metal cation-binding sites. Acta Crystallogr D Biol Crystallogr 2007;63:240-8.

2. Holmberg GC. On the presence of laccase like enzymes in Nerum and it's relation to the copper in serum. Acta Physiol Scand 1944;8:227-9.

3. Takahashi N, Ortel TL, Putnam FW. Single-chain structure of human ceruloplasmin: The complete amino acid sequence of the whole molecule. Proc Natl Acad Sci U S A 1984;81:390-4.

4. Zaitseva I, Zaitsev V, Card G, Moshkov K, Bax B, Ralph A, et al. The $\mathrm{X}$-ray structure of human ceruloplasmin at 3.1 A: Nature of the copper center. J Biol Inorg Chem 1996;1:15-23.

5. Linder MC. Nutritional biochemistry of copper, with emphasis on the perinatal period. In: Avigliano L, editor. Biochemical Aspects of Human Nutrition. Trivandrum, Kerala, India: Research Signpost; 2010. p. 143-79.

6. Nevitt T, Ohrvik H, Thiele DJ. Charting the travels of copper in eukaryotes from yeast to mammals. Biochim Biophys Acta 2012;1823:1580-93.

7. Fukai T, Ushio-Fukai M. Superoxide dismutases: Role in redox signaling, vascular function, and diseases. Antioxid Redox Signal 2011;15:1583-606.

8. Vashchenko G, MacGillivray RT. Multi-copper oxidases and human iron metabolism. Nutrients 2013;5:2289-313.

9. Lutsenko S. Human copper homeostasis: A network of interconnected pathways. Curr Opin Chem Biol 2010;14:211-7.

10. Harris ZL, Durley AP, Man TK, Gitlin JD. Targeted gene disruption reveals an essential role for ceruloplasmin in cellular iron efflux. Proc Natl Acad Sci U S A 1999;96:10812-7. 
11. Collins JF, Prohaska JR, Knutson MD. Metabolic crossroads of iron and copper. Nutr Rev 2010;68:133-47.

12. White KN, Conesa C, Sánchez L, Amini M, Farnaud S, Lorvoralak $\mathrm{C}$, et al. The transfer of iron between ceruloplasmin and transferrins. Biochim Biophys Acta 2012;1820:411-6.

13. Kono S. Aceruloplasminemia: An update. Int Rev Neurobiol 2013;110:125-51.

14. Linder MC. Biochemistry of Copper. New York: Plenum Press; 1991

15. Anderson GJ, Frazer DM, McKie AT, Vulpe CD. The ceruloplasmin homolog hephaestin and the control of intestinal iron absorption. Blood Cells Mol Dis 2002;29:367-75

16. Messerschmidt A, Ladenstein R, Huber R, Bolognesi M, Avigliano L, Petruzzelli R, et al. Refined crystal structure of ascorbate oxidase at 1.9 A resolution. J Mol Biol 1992;224:179-205.

17. Lindley PF. Handbook on Metalloproteins. New York: Marcel Dekker; 2001. p. 763-811.

18. Lindley PF, Card G, Zaitseva I, Zaitsev V. Perspectives on Bioinorganic Chemistry. Vol. 4. Greenwich, CT, USA: JAI Press; 1999. p. 51-89.

19. Nakamura K, GO N. Function and molecular evolution of multicopper blue proteins. Cell Mol Life Sci 2005;62:2050-66.

20. Almekinder J, Manda W, Soko D, Lan Y, Hoover DR, Semba RD, et al. Evaluation of plasma retinol-binding protein as a surrogate measure for plasma retinol concentrations. Scand J Clin Lab Invest 2000;60:199-203.

21. Baeten JM, Richardson BA, Bankson DD, Wener MH, Kreiss JK, Lavreys L, et al. Use of serum retinol-binding protein for prediction of vitamin A deficiency: Effects of HIV-1 infection, protein malnutrition, and the acute phase response. Am J Clin Nutr 2004;79:218-25.

22. Peters T Jr, editor. All about Albumin: Biochemistry, Genetics and Medical Applications. San Diego, London: Academic Press; 1996.

23. Evans TW. Review article: Albumin as a drug-ßiological effects of albumin unrelated to oncotic pressure. Aliment Pharmacol Ther 2002;16 Suppl 5:6-11.

24. Curry S, Mandelkow H, Brick P, Franks N. Crystal structure of human serum albumin complexed with fatty acid reveals an asymmetric distribution of binding sites. Nat Struct Biol 1998;5:827-35

25. Kragh-Hansen U, Chuang VT, Otagiri M. Practical aspects of the ligand-binding and enzymatic properties of human serum albumin. Biol Pharm Bull 2002;25:695-704.

26. Bocedi A, Notaril S, Narciso P, Bolli A, Fasano M, Ascenzi P, et al. Binding of anti-HIV drugs to human serum albumin. IUBMB Life 2004;56:609-14.
27. Ghuman J, Zunszain PA, Petitpas I, Bhattacharya AA, Otagiri M, Curry S, et al. Structural basis of the drug-binding specificity of human serum albumin. J Mol Biol 2005;353:38-52.

28. Fanali G, Bocedi A, Ascenzi P, Fasano M. Modulation of heme and myristate binding to human serum albumin by anti-HIV drugs. An optical and NMR spectroscopic study. FEBS J 2007;274:4491-502.

29. Yang F, Bian C, Zhu L, Zhao G, Huang Z, Huang M, et al. Effect of human serum albumin on drug metabolism: Structural evidence of esterase activity of human serum albumin. J Struct Biol 2007;157:348-55

30. Gupta D, Lis CG. Pretreatment serum albumin as a predictor of cancer survival: A systematic review of the epidemiological literature. Nutr J 2010;9:69.

31. Koga M, Kasayama S. Clinical impact of glycated albumin as another glycemic control marker. Endocr J 2010;57:751-62.

32. Sbarouni E, Georgiadou P, Voudris V. Ischemia modified albumin changes - Review and clinical implications. Clin Chem Lab Med 2011;49:177-84

33. Bertucci C, Pistolozzi M, De Simone A. Circular dichroism in drug discovery and development: An abridged review. Anal Bioanal Chem 2010;398:155-66.

34. Furukawa M, Tanaka R, Chuang VT, Ishima Y, Taguchi K, Watanabe H, et al. Human serum albumin-thioredoxin fusion protein with long blood retention property is effective in suppressing lung injury. J Control Release 2011;154:189-95.

35. Komatsu T, Qu X, Ihara H, Fujihara M, Azuma H, Ikeda H, et al. Virus trap in human serum albumin nanotube. J Am Chem Soc 2011;133:3246-8.

36. Jyothi P, Yellamma K. Molecular docking studies on the therapeutic targets of Alzheimer's disease using natural bioactive alkaloids. Int $\mathrm{J}$ Pharm Pharm Sci 2016;8:108-17

37. Heba M, Salem A, Khadega M, El Hallouty S, Eslam R, El Sawy E, et.al. Synthesis, molecular docking and anti-proliferative activity of new series of 1-Methyl Sulphonyl 3-indolylhetrocycles. Int J Pharm Pharm Sci 2016;8:113-23.

38. Bikadi Z, Hazai E. Application of the PM6 semi-empirical method to modeling proteins enhances docking accuracy of autoDock. J Cheminform 2009;1:15.

39. Morris GM, Goodsell DS, Halliday RS, Huey R, Hart WE, Belew RK, et al. Automated docking using a Lamarckian genetic algorithm and an empirical binding free energy function. J Comput Chem 1998;19:1639-62.

40. Solis FJ, Wets JB. Minimization by random search techniques. Math Oper Res 1981;6:19-30. 